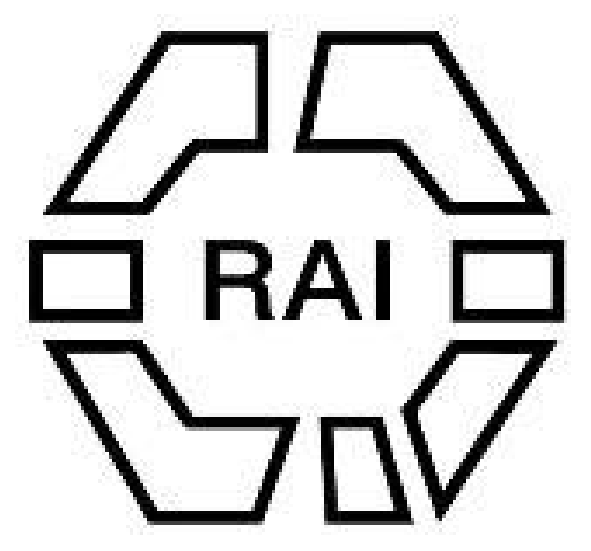

\title{
WILEY
}

Fijian Heralds and Envoys.

Author(s): A. M. Hocart

Source: The Journal of the Royal Anthropological Institute of Great Britain and Ireland, Vol. 43 (Jan. - Jun., 1913), pp. 109-118

Published by: Royal Anthropological Institute of Great Britain and Ireland

Stable URL: http://www.jstor.org/stable/2843163

Accessed: 18-04-2016 23:39 UTC

Your use of the JSTOR archive indicates your acceptance of the Terms \& Conditions of Use, available at

http://about.jstor.org/terms

JSTOR is a not-for-profit service that helps scholars, researchers, and students discover, use, and build upon a wide range of content in a trusted digital archive. We use information technology and tools to increase productivity and facilitate new forms of scholarship. For more information about JSTOR, please contact support@jstor.org.

Royal Anthropological Institute of Great Britain and Ireland, Wiley are collaborating with JSTOR to digitize, preserve and extend access to The Journal of the Royal Anthropological Institute of Great Britain and Ireland 


\section{FIJIAN HERALDS AND ENVOYS.}

\section{By A. M. Hocart.}

The study of kinship involves a great deal more besides relationships and laws of marriage ; it is inseparable from the study of social institutions, whether these are the outcome or origin of kinship customs. Of this interaction Fiji offers many an instance from which I select two, heraldry and diplomacy, for the joint subject of this paper.

I begin with heralds.

First, let me summarize, for those who are ignorant of the literature, the nature and functions of Fijian heralds. The Eastern Fijians ${ }^{1}$ call them mata ni vanua, that is "eyes of the land"; the word mata has, however, lost its figurative sense and has come to mean a messenger, an envoy, and lately a gazette. Their functions are chiefly connected with feasts and presentations of fabrics (iyau); it is their duty to speak the compliments or apologies that always accompany a gift, or to acknowledge one on behalf of their chief; they make out the portions of a feast and call out the names of the recipients; at kava-making they keep an eye on the beverage and determine the amount of water and of straining. For our purpose it is important to note that the herald is sent on errands and that he is specially connected with the distribution of food: that in many places in the hills, if not everywhere, he has the exclusive right of eating up the leavings of the chief; that he is the chief's constant attendant at meals and at kava ; is humble in his presence, and yet claims, and is acknowledged, to come next to the nobility in rank.

If we look for the kindred that most closely resemble the chief and his herald in their mutual relations, we shall surely fix upon elder and younger brothers. Here are some of the rules which Alipate Vola of Lakemba deems it proper for such relatives to observe-

"A younger brother may not take the property of the elder, but the converse is possible to an extent which depends upon the elder; . . . brothers in the nobility do not talk for the sake of talking, or cheerfully; . . . . . the elder addresses the younger."

The deference shown by the cadet to the senior is a familiar sight; while all the other people present sit round in an oval with little respect to rank, the younger brother always sits at the end near the door, and never seems to face his elder brother nor yet to turn his back to him.

${ }^{1}$ By Eastern Fijians in this paper I mean Fijians east of the Tomaniivi and Muanivatu range in Viti Levu; by Western Fijians those west of that range. 
A man's own younger brother, born of the same father and mother, is called his "after eater" (kana e muri), because he waits till his brother has finished in order to fall to. It is also the duty of the youngest to look after the food baskets, which used to be hung up at the lower end of the house. In a heated discussion an opponent of inferior station will be silenced by the remark: "Do not speak, you are he that sits by the food basket." The younger brother is also called "the basket bearer" because he bears all the burdens.

In Lakemba these rules apply ouly to own brothers, not to the mass of half or tribal brothers, for the excellent reason that it is impossible to determine the order of seniority. A man is not "after eater" to his half-brother because, as one informant told me, "in polygamous days there were always a number of wives pregnant at one time, and so the order was not plain." Yet great respect is shown to certain prominent persons among the tribal brothers, namely, the eldest descendant of the eldest son. Sons of great ladies, or leading members of a family also form the centres of groups consisting of own brothers, tribal brothers of inferior rank or "small brothers," and bastards, these are dependent upon him and sent on errands. I shall take instances from the pedigree of the Lakemba nobility. I shall only give of this extensive genealogy such a fragment as will be of use in the course of this paper.

Vola will observe the strictest silence and modesty in the presence of Salesi, the eldest son of the eldest son of Kilai, and the most important person in the $\operatorname{clan}^{1}$ of Vatuwangga; also in the presence of Liwake, as eldest son of a younger son of the eldest son of Malani, the elder. Apart from Finau, who, as High Chief, commands the respect of every one, he does not show the same deference to others ; for the senior branch of Naivi has been worsted in civil war by the juniors. On his mother's side Salesi can use Ratu as his messenger, because Maopa is a "little sister" (tadhinggu lailai) to Melaia."

I claim no credit for noticing the analogy between heralds and younger brothers; as often happens in intensive study of a small area, the theory turned up as a fact before it could be imagined as a hypothesis.

It is the west that shows us heraldry in what seems to be its most primitive form, as indeed the west has generally a more rudimentary sucial structure. In Tukuraki, in the hills south of Neilanga, ${ }^{3} \mathrm{Mba}, \mathrm{I}$ was informed that the mata ni vanua was Madhiu of the clan of Nakula, because he "stands right behind in the order of nobles." A Rakiraki man commented : "The youngest branch are servants, make food for the chief's, and are sent on errands." I had no time to get pedigrees, but I learnt that the men of Nakula were divided into four " halls "4 in the following

1 I translate thus matanggali although it is not now, in most parts of Fiji, an exogamous group.

${ }^{2}$ It will be noticed that the marriage of Isoa and Melaia is one between relations who formally ought not to marry ; this is common in the nobility.

3 Officially Nailanga, but that is a Mbauan form. I have to express my thanks to Mr. Lelean of Nailanga for directing me to that village and giving me every assistance in getting there.

4 Mbeto; Mbauan : mbure. 


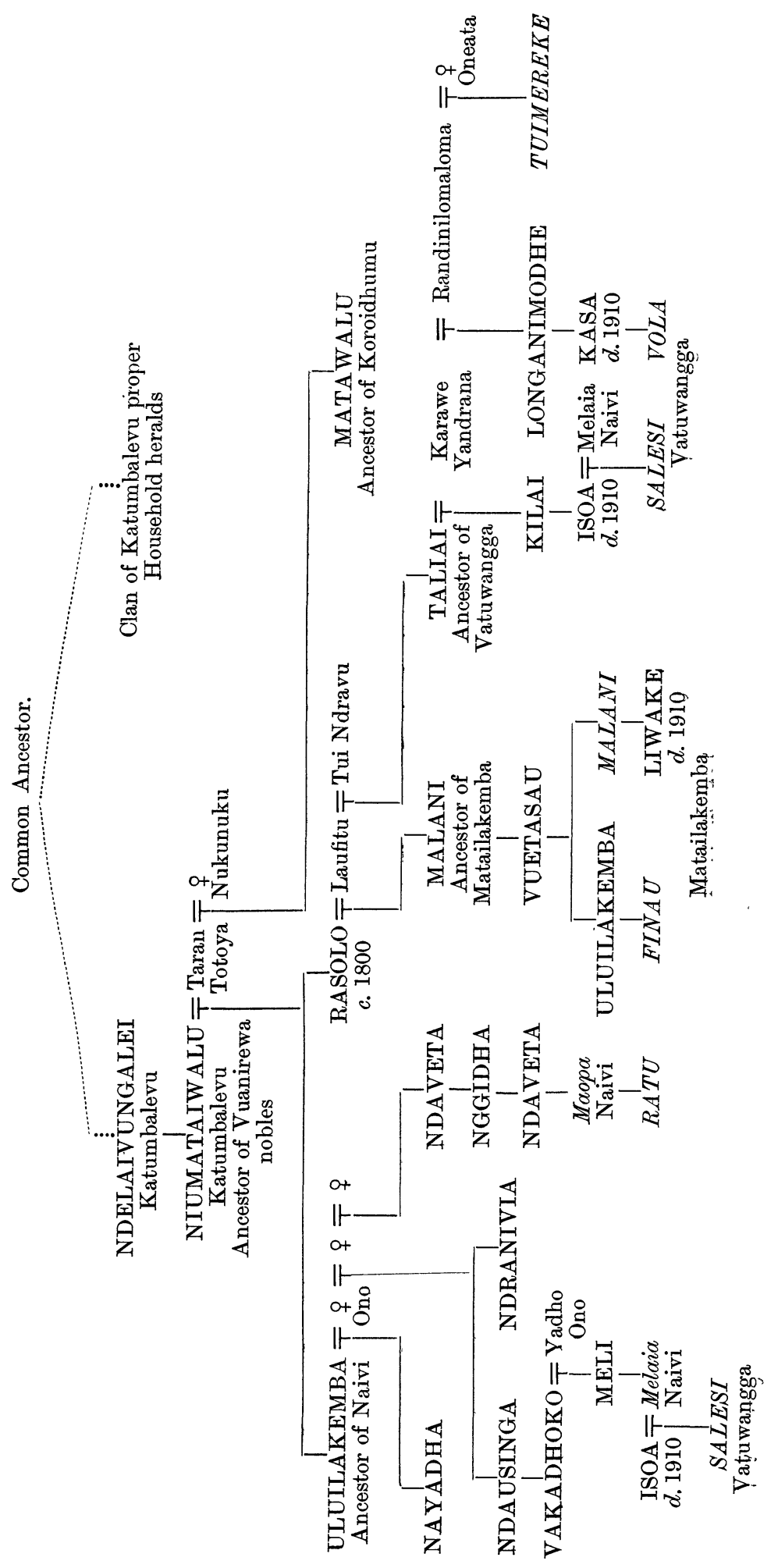


order : (1) Koroilengga ; (2) Natawa ; (3) Makaia ; (4) Nakorosovivi. Now it is an accepted doctrine in Fiji that all members of a clan are of common descent, and that the halls composing it represent branches of one family. ${ }^{1}$ This tends to confirm the Rakiraki man's rule.

I was not aware at the time that the term mata ni vanua is foreign to the west, and that the Tukuraki people were merely translating by it a local term. In Neilanga they call the herald na tutu, i.e., the stander, because he alone may stand in the presence of the ehief. Besides certain functions not fulfilled by eastern heralds, he has the usual one of proclaiming what the chief has to say, and apportioning the food. That post in Neilanga is held by the clan of Taumbere, who are "brothers" (tadhini) to the leading clan of Tio and are, in fact, but the younger branch of the same family ; the name Taumbere merely means "born late."'

In Nakoromboya, a village of the Nggaliyalatini tribe, there seemed to be no family of heralds, although the name and functions of na tutu were perfectly well known. The institution ean hardly have been very formal.

The village of Navai in the Numbu tribe does not use the word na tutu, but translates mata ni vanua by nduve; another title is ndrau ni masi, or "sheet of bark-cloth," a term applied to the last born because the tapa is first cut off for the eldest, then for the next brothers, the cadet getting what is left. The herald used to be nanunukawa, "the lowest of men, he was sent on errands, received orders, ate the leavings of the ehief's food, went on ahead to give notice." It is doubtful how far his office is formal enough to deserve the title of herald, how far it is even an office. My informants by translating nduve by mata ni vanua misled me into assuming that he is a formal herald; but carefully considering their description and manner of speaking, we are compelled to doubt whether he is in any sense an official and master of ceremonies; this uncertainty as to his status will prove a serious hindrance to our researches into the origin of Fijian heralds.

Ngaloa, near Serua, on the southern coast, belongs in culture to the western tribes. I was told that mata ni vanua was the local title. In the Koroyanitu tribe he is drawn from the family of Maruselino, who is "younger brother to the chief, and the lowest too." His division (itokatoka) of Nambili stands in the relation of younger brothers to the division of elder brothers from which the chiefs are elected. My informant spoke of them as the chief's "serfs," they are sent on errands night and day; they roast food at night."

When I asked Seremaia of Neilanga, Mba, whether they had ikaso (bastards) ${ }^{5}$

${ }^{1}$ Cp. Fison : Land Tenure in Fiji, Suva, Government Printer, 1903. Pp. $3 \mathrm{ff}$.

2 Mbauan : sudhu mbera.

${ }^{3}$ Kaisi: the term is very relative; the general meaning is low born; but the expression nona tamata kaisi," his own low born men, means that they have to do all his bidding; the word serf is therefore not inapplicable.

${ }^{4}$ Roast food is a delieacy which requires constant watching while cooking; it is not usually prepared for common folk, except when sick.

5 Ikaso is properly the son of a nobleman by a woman of inferior rank or handmaid, the union of the parents not being official. 
in Mba, he explained it as a Mbauan word meaning "younger brothers, and they are heralds (mata ni vanua)." In the west they have no bastards (ikaso), as descent through the mother does not affect rank; Seremaia's confusion, therefore, between younger sons and bastards is natural, and his identifying both with heralds instructive.

Let us now cross over the dividing range into the east with its more complex social organization. I could find no evidence of a connection between heralds and younger brothers till Nakorosule on the Upper Rewa, and there it seems at first adverse, for the half tribe of Waimaro is divided into three clans : Nakoronduandua, Waimaro proper, and Lase, which claim to be descended from the three sons of Nggamau : Naloa, Matanakanadhe, Tuitokatoka. Now the herald clan is not the youngest but the second, and the chief's clan is not the eldest but the youngest. It is an exception, however, that proves the rule, for the primacy of Tuitokatoka was viewed as abnormal, and ever since the eldest son in Nakorosule has been stupid and the youngest intelligent. Moreover, Nakoronduandua enjoy a certain dignity without power which appears in the fact that a man whose mother comes thence is a great noble, while sons of a Waimaro woman are heralds.

Social organization in Nodho, Rewa delta, seems to have reached a considerable degree of symmetry and complication. The nobles are divided into four clans: Mbatingga, Vunivutu, Nadhonggona, Naloarumbe; to each of these is attached a clan of heralds in the respective order: Naiviyate, Natuki, Tadhi, Naisongovau. Tadhi means younger brother, and my informants, both of Mbatingga, said that. these four herald clans were the bastards.

Emosi, the herald of the Lakemba chief, explains his position by his descent from Saunikalou, the youngest of three brothers; the eldest, Vunisau, is the ancestor of the present nobility. The tradition is doubtful, but, if it was invented, it was invented according to a model by some one who knew cases in which the heralds were descendants of younger sons; I doubt, however, whether a Fijian would make such a discovery unless it was very evident, for they are as ignorant of each other's customs as British, say, of Russians.

In Lakemba there is another clan of heralds, the household heralds (mata ni vanua $e$ vale); this is the clan of Katumbalevu proper. I must explain that Katumbalevu is used in two senses; firstly, to include both the nobles, called Vuanirewa, and their household heralds, and secondly to designate the latter exclusively. The Vuanirewa and Katumbalevu proper were originally one ; when exactly they split is not known, but it probably dates from Niumataiwalu, the common ancestor of the Vuanirewa, about one hundred and twenty years ago certainly not before. Here, then, we have historical evidence of heralds belonging to the same clan as the nobility and therefore presumably of common descent with them. We can also see how it comes that a tribe is so often called, not after the name of the leading clan, but after that of the heralds.

Thus we have found that in the west cadets fulfil menial services such as are VOL. XLIII. 
assigned to the heralds in the east, and are, in fact, identified with these heralds. The eastern evidence might be somewhat weak in itself, but the west justifies us in making capital of it, and concluding that most mata ni vanua, or, at any rate, the earliest, were originally cadets or bastards, though the growth of population and the consequent splitting up of families into clans may have generally obscured the fact by placing the heralds in a different clan from their chiefs.

Our first impulse is to conclude that the heralds were evolved out of the rules of primogeniture: they are merely younger brothers of the chief, and exercise towards him the same functions, only exalted and rendered official by the growth of Fijian society. But there is an opposite theory, suggested to me by Dr. Rivers, which seems equally plausible, namely, that full-blown heralds came in with an invading race, and that their functions were assigned, by all tribes that adopted the office, to the younger brother; thus the etiquette of primogeniture would be copied from heraldry and not vice versa. On the one hand, there can be no doubt that heraldry, as indeed the whole pomp and circumstance of the eastern tribes, has been developed under foreign influence, or by another race than the present-day Fijians; on the other hand, it is hard to believe that an informal institution such as we guess the nduve to be, is a copy of the complete herald. The uncertain character of the nduve compels us to suspend judgment.

In the present state of affairs a compromise between the two theories suggests itself as the most likely, namely, that the functions of the younger brother are earlier; that they gave rise in the west to the despised cadet of the clan doing menial service for his seniors; that under foreign influence these developed into formal heralds enjoying great consideration, and standing next to the nobles in the social order. This would account for a discrepancy between the status of a younger brother and that of a herald which we have rather slurred over; the herald sits beside his chief and directs the whole proceedings, a thing we have never seen done by a younger brother.

Such then would seem to be the origin of heralds within the limits of the Fijian archipelago, but the ultimate origin would be transferred beyond its boundaries to Polynesia; Tonga has heralds that resemble their Fijian colleagues too closely to let us believe that there is no connection between them. A survey of Tonga might give one a clue to their origin, or throw some light upon their interaction with the Fijian institution. The claims of the rival theories, might, however, be settled by a better knowledge of Western Fiji.

I was careful to conclude no more than that most heralds have been younger brothers, for here is, at least, one exception.

Lomaloma in Vanua Mbalavu has two chiefs; the one called Rasau has his heralds in Ndakuilomaloma, a village on the other side of the island. The origin of their dignity was recorded at my request by Keni Naulu : "the mother of this chief (Nggalidha) came from Ndakuilomaloma. His village was Na Korolevu; but sometimes he would go down to Ndakuilomaloma to stay there; now at that time there were in Ndaku some men of Yandrana (on the north coast of Lakemba) of the clan 
of Kelo, as Mbudha (Nggalidha's clan) and Yandrana are tauvu. ${ }^{1}$ While Rasau was in Ndaku they appointed a man of Kelo to be herald to Rasau. The reason why the Ndaku people are heralds is that the men of Kelo dwelt there." I show elsewhere ${ }^{1}$ that tauvu is founded on intermarriage, and that tauvu clans are crosscousins. Here, then, we have a case of heralds derived from cross-cousins.

We might be tempted to trace the institution of envoys or ambassadors to the same source as the heralds, but though their functions are not unlike, their names similar, and writers like Waterhouse confuse them, we must postulate a different origin.

The envoys are called mata $k i$ with the addition of the place to which they are accredited, thus mata ki Mbau is the envoy to Mbàu. Williams speaks of "a diplomatic corps, the official title of each individual of which contains the name of the place to which he is a messenger . . . When on duty these officials represent their chief . . ." Such expressions as a "diplomatic corps" and "officials" are, of course, misleading, there is no such formal office; the duties belong to the clan and not to the individual, and every clan (at least in Tumbou, of which Williams is speaking) has a place to which it is envoy.

We cannot do better than compare them to the Greek xenos; not only do they convey messages to a specified place, but they receive visitors thence, entertain them and introduce them to the chief.

The custom is falling into decay, but even now, if one wishes to find a Kambara man in Tumbou, Lakemba, one is quite safe in looking for him in the Lord of Tumbou's quarters, for this personage and his clan of Tanggalevu are envoys to Kambara and keep up the old ways; when one of the clan was ill with consumption, he went for a change to Kambara, and also to live on his kinsmen there. Some two years ago Kasa of Vatuwangga, the clan of envoys to Modhe, told the people of that island to build themselves a house within his enclosure as a kind of "pied à terre." On the other hand, if Tongan or Mbauan visitors of note came to Lakemba, a member of Vatuwangga, say, would be dispatched to Modhe to order tapa, a nobleman of Naivi to Ono to commandeer sinnet, and so forth.

Such is the custom in Eastern Fiji. But in looking for clues it is best to address oneself first to the west, which is, socially, less highly organized.

On the western coast from Nandronga to Vunda there exists an institution called matekila or, in Nandronga dialect, masekila.

The matekila of Nandronga are Nandi, Sambeto, and Vunda; "It is a question of relationship" ; Navatukandiri (the chipped stone) is the " root" of the relationship between Nandronga and Nandi; Vatuhorihori between Nandronga and Sambeto; Neilawanitawa connects Nandronga and Vunda. If Nandronga and Nandi are at war, peace is made by the clan of Vunavesi in Nandronga taking whales' teeth to Nandi, or the clan of Navatulevu in Nandi taking whales' teeth to Nandronga; in either case "their very first word" is Navatukandiri. In offering the whales'

\footnotetext{
1 See "The Fijian Custom of Tauvu," p. 101, above.
} 
teeth the envoys of Vunavesi will say, for instance: "I present this whale's tooth, a small tooth, that you may be gracious, that there be no war, that we may be at peace: long is my speech by the Vatukandiri in Louvatu, o kei a tū." Navureimbuto is the clan of the envoys to Sambeto; Mataimburembahanga ${ }^{1}$ are sent to Vunda and the two are "true relatives."

An informant from Vunda writes: "The people of the village of Viseisei stand in the relation of matekila to those of Sila (the Mataimburembahanga), a village of Nandronga; the reason is simply that they are descended from our ancestors. Whenever the people of that village come to Vunda they will kill pigs and fowls without leave and carry off without leave food and fabrics, and our elders do not once resent it. Our elders will also go to their village and do the same. . . . If war breaks out on the Nandronga side they come to our elders to side with them. . . . It goes on to the present day." The last sentence refers to the free use of each other's property : this is a regular accompaniment of connubium, and the right of cross-cousins all over Fiji.

A Nandi man describes the sameright of appropriation between the matekila clans of Naombekwa in Namotomoto, and Lasakau in Namoli, and thinks "it must be due to women ; a long time ago a woman of Naombekwa went to Namoli."

In $\mathrm{Mba}$ the people appear to have nothing so formal as the matekila, and it is not certain how far the word is part of their vocabulary. However, their definition is valuable : Ananayasa of Kumbuya suggests veitavaleni (cross-cousins) as equivalent of matekila and explains that if a woman of Tio marries into Vitongo, her daughter, who is sister's child (vasu) to Tio, marries back into Tio, has issue, and so the two tribes go on intermarrying, and are veimatekila.

Our western experience teaches us, therefore, that a clan may be selected as envoys to a tribe because they intermarry with that tribe.

Let us apply this clue to the Lakemban facts. Here is the list of the clans of Tumbou, where reside the nobility, and the various islands to which they are envoys-

\footnotetext{
Naivi to Ono, Ongea, Vatoa ;

Matailakemba to Namuka;

Vatuwangga to Vulanga and Modhe ;

Koroidhumu to Oneata;

Katumbalevu proper to Dhidhia;

Dheyekena to Komo ;

Tanggalevu, or Tumbou proper, to Kambara.
}

All these islands are subject to Lakemba. Envoys to other places are arbitrarily chosen, except the.envoys to Mbau, who are appointed from among the heralds (mata ni vanua) of the clan of Narewandamu.

The first four clans constitute the nobility and are of common origin with the fifth. The second and third are eligible to the high chieftainship. 
People of quality had so many wives from so many different islands that a genealogy might justify an envoyship to one place as well as another. But the intermarriage of Naivi with Ono seems most decidedly preponderant, and we must count under the same heading all intermarriages between Naivi and Wadhiwadhi in Lakemba, for Ono being a colony of Wadhiwadhi, anyone related to the second is also related to the first. I must ask the reader to take these facts upon trust as I have not the complete pedigrees to hand. Nayadha and his mother's brother challenged each other; in the consequent siege Nayadha at once conquered Ono and protected it, as sister's son, against further harm; that was no doubt the foundation of their envoyship. Tshutshua (Joshua) of Naivi, however, appears to have no connection by marriage with Ono and looks upon Nggalinggali in Kambara as his peculiar place, by reason of a female ancestor from that place, Ndranivia's wife, if I remember well.

Vatoa belongs to Ono.

Koroidhumu's case seems plain: Matawalu's mother came from Nukunuku, and the Oneata chiefs come from Nukunuku in Lakemba; a sister's son (vasu) to Nukunuku is therefore sister's son to Oneata. In point of fact Matawalu once saved Oneata from the aggression of his own people, "because," says Sakaraia, Lord of Oneata, "Matawalu and Mbalemalua (chief of Oneata) were cross-cousins."

The following diagram will illustrate this :-

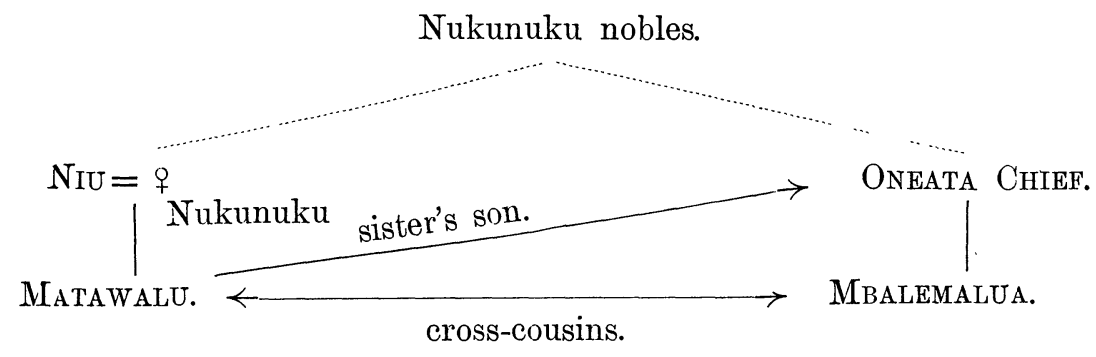

Sakaraia also said that Tuimereke (by birth of Vatuwangga; by adoption of Naivi) would be sent as envoy to Oneata, because his mother was a lady of that place.

Tanggalevu marries a good deal with Kambara. One informant says they are one family. Kambara men also declared that "the ladies" are the cause of our coming : in course of time they (Tanggalevu) were appointed envoys to Kambara."

The evidence is meagre, but considering that most of these appointments are fairly recent, dating from a time when intertribal suspicion was weakened, and when no one of these islands would have disregarded any Lekemban envoy, whoever he might be, we must be thankful that we have found any envoyships based upon intermarriage at all.

Within the island of Lakemba there are no envoys, but there exist similar though less formal and more personal connections. The expression used for the Tumbou xenos of the Lakemba village is that he is a "native" (itaukei) in that village. If we ask what noblemen are "native" in Wadhiwadhi, they will answer

1 i.e., of one place married into the other. 
that anyone whose mother comes from Ono is " native" in Wadhiwadhi. Salesi is xenos of Yandrana through his grandfather's mother ; his influence is predominant there, and if the Yandrana folk have any request to proffer to the High Chief, they will address themselves to Salesi, who will introduce them at the "Great House."I It is thus but another form of the sister's sonship (vasu) and envoyship.

Akeai of Matuku says that " of old the islands of Moala and Matuku held no intercourse $^{2}$; if a man of one island went to the other, he was clubbed; but there were relationships between them. . . . If I wished to hold a ceremonial exchange (solevu), I saw my kinsmen of Moala and informed them first; if they approved, it was done." Even at the present day a Fijian is not fond of travelling to places where he has no relatives. Melaia thinks it is useful to know one's mother's pedigree, as visiting a place a man will thus know whose house to stay at, and thinks her son takes no interest in his mother's relatives because he is not given to travel.

I have it on record that the chief of Namosi being at war with the tribe of Korolevu ${ }^{3}$ sent them a young nobleman whose mother was of Korolevu, with offers of peace.

We are safe in concluding that the same theory holds good of eastern as of western envoys; a man is sent to his mother's kinsmen because he is safe among them and because he is sure, in virtue of the sister's son's irresistible right (vasu), to obtain what he asks for. This usefulness of the sister's son may in turn have reacted upon his right and helped it to the extreme pitch to which it has attained in Fiji. Subject tribes especially would have to cultivate a person who could at any time be required to shield them.

That the evidence is scanty need not be wondered at; no great event has accompanied the growth of this institution, such as marked the setting up of chiefs; it has grown imperceptibly, and therefore no one has remembered its origin once intercourse between tribe and tribe had become general; and this same intercourse makes it hopeless to prove by genealogies a greater number of marriages of envoys with their corresponding tribe than of other clans.

Once the pattern was set, arbitrary copies could be made, and persons appointed envoys at the will of the chief. The Mbauan envoys to Dhakaundrove, Lakemba, Naitasiri, are selected among the heralds who were certainly not connected with those places before their lords. The same applies to the Lakemban envoys to Mbau. Naivi is envoy to Ongea because Tailiai gave that island to a nobleman of Naivi who bailed out his canoe in a storm. In Naitasiri the envoys to Mbau are the first clan to have visited Mbau and secured, not for themselves, but for their lords, a Mbauan wife.

These new formations (all are new that are known to me) were doubtless promoted by the increasing pomp and dignity of the nobility, who came to look upon the duties of envoy as more suited to the heralds than to themselves.

1 i.e., the chief's house.

2 This is an example of the Fijian way of expressing as absolute a qualified statement. The sequel shows there was intercourse, only it was not a daily event, an enterprise without special reason.

3 Now in Serua, south coast. 